\title{
LCD 光学フィルム用粘着剂の開発 Development of Pressure Sensitive Adhesive for LCD Optical Film
}

\section{1. 緒 言}

液晶ディスプレイ（以下 LCD）は，1970 年代初頭に表 示デバイスとして初めて製品化されて以来, 独自の新しい 用途を生み出すことで市場を拡大してきた。電卓に始まり, デジタルウオッチ, PDA, 携帯電話, ノート PC, カーナ ビゲーションへと続く流れである。近年では, 薄型・省ス ペース・目に優しい表示といった LCDの優位性を十分に 活かすことで，かつて CRT が独占していた PC 用のモ二 夕一市場を席巻するという動きとなっている。さらに, CRT の主戦場であり最大の市場である TV 分野への進出 あ進んでいる。フラットパネルディスプレイとしては, LCD に加え，プラズマディスプレイ（以下 PDP）やリア プロジェクションなど，様々な方式が市場に登場している。 いずれもそれぞれの特徵を活かす形で TV 市場に参入し てきたが，現在では，LCDの TV 市場に占める割合が非 常に大きなものとなってきている。

これらのフラットパネルディスプレイには，それぞれの 方式で内容に違いはあるすのの, 様々な光学フィルムが使 用されている。代表的なむのとしては，LCD であれば液 晶表示を行うための偏光板であり，PDPであれば外光の 写りこみを抑えるための AR（アンチチリフレクション） フィルムなどが挙げられる。この中でも, 特に多くの種類 の光学フィルムを使用しているのが LCD である。

一般的な LCD の構造の断面図を図 1 に示す。前述した

*日東電工(梸)オプティカル事業本部 技術開発部門 第 1 開発部

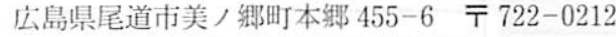

NITTO DENKO CORPORATION

DEVELOPMENT DEPT.1 DEVELOPMENT SECTOR OPTICAL BUSINESS HEADQUARTERS

455-6, Hongo, Minogo, Onomichi, Hiroshima, 722-0212, Japan

(平成 20 年度日本接学学会技術賞受賞)
佐竹 正之* Masayuki SATAKE

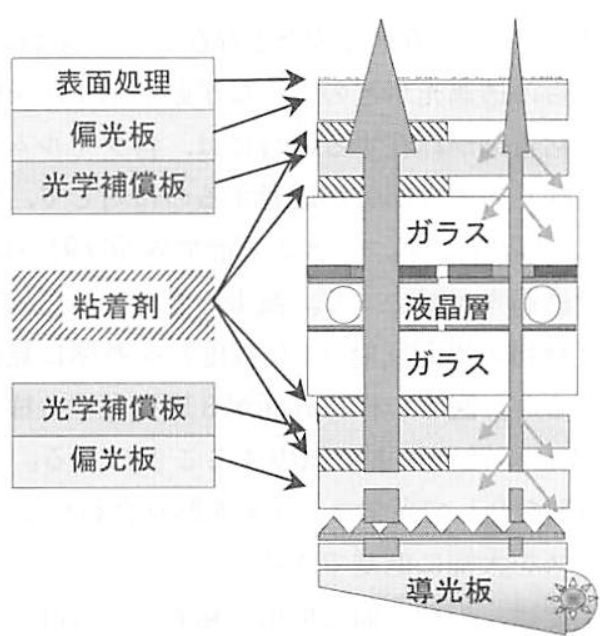

図 1 LCD の断面構造

偏光板は, 一定方向の直線偏光のみを透過し，それと $90^{\circ} \mathrm{C}$ 方向の光を吸収する性質を持ったフィルムである。通常は LCD パネルの上下に各 1 枚づつ，両方のフィルムがクロ スニコル状態になるよう配置される。LCD の電圧を ON・ OFF することで光を透過・遮断するシャッターの役割を 果たしており，これを様々に組み合わせることで画面表示 を行っている1)。

さらに，ディスプレイとして表示品位を向上させるため

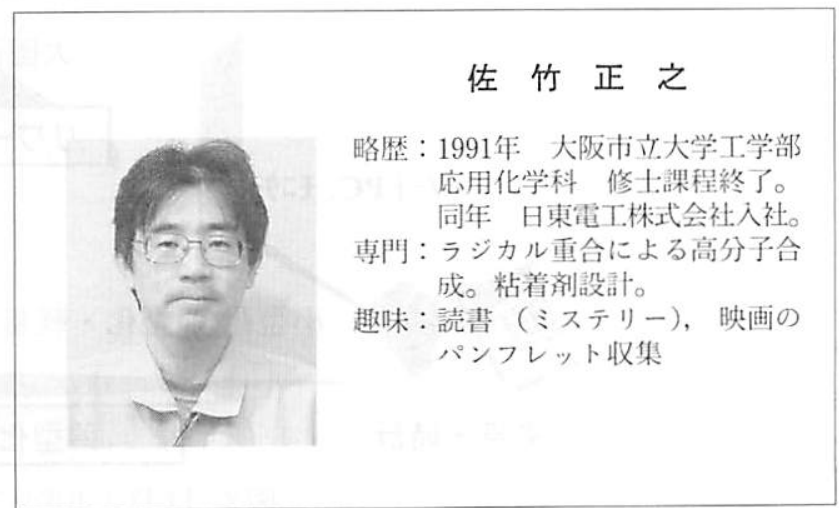


に種々の光学フィルムを組み合わせて用いることが一般的 である。液晶の光学補償を行うことで表示の色や視野角を コントロールするフィルムとしては, 位相差板 ${ }^{2 \sim 4)}$ や視野 角拡大フィルム ${ }^{5}$, 画面を明るくするために輝度を向上さ せるための輝度向上フィルム ${ }^{6)}$, 外光の移り込みや画面の 白ボケを抑制するために，ディスプレイ表面の状態をコン トロールする $\mathrm{AR} や \mathrm{AG}$ (アンチグレア) フィルム ${ }^{7,8)}$, などである。

これらのフィルムは偏光板に積層されて用いられるが, フィルム同士の貼り合せには粘着剤が使用されている。さ らに, 樻層された光学フィルムを LCD セルのガラス基板 に固定するためにも粘着剤が用いられる。これらの貼り合 せに粘着剤を使用する理由として，作業の利便性，生産効 率性, 信頼性を確保するなど様々な事柄が挙げられるが, 光学的にも大きなメリットがある。

図 1 には粘着剤が存在する場合と存在しない場合に, バッ クライトからの透過光がどのような挙動を示すかを模式的 に示した。粘着剤が存在する場合には，各フィルムや液晶 での吸収を除く光の大部分が透過するのに対して, 粘着剤 が存在しない場合は, 各フィルム界面で界面反射が起こり, その分だけ透過光が減少する。減少の度合いは一般的なプ ラスチック材料の界面反射（4\%程度）を基準に見積もる ことができるが，図 1 の様に界面が 8 層存在する様な場合

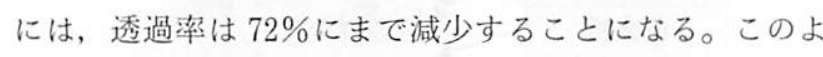
うに, 粘着剤を介して光学フィルムを貼り合わせることで, 透過光のロスを大幅に低減できる ${ }^{9)}$ 。

日東電工では, 当初, 偏光板用の粘着剤を設計, 量産す る形で液晶市場に参入し, 現在では, 偏光板を始めとする 様々な光学フィルム自体を設計, 量産することで, LCD 用粘着光学フィルムの世界市場の約 50\%（2006 年度日東
電工調べ）のシェアを得るに至った ${ }^{10)}$ 。これらの新しい $\mathrm{LCD}$, 新しい光学フィルムに対して必要な粘着剤特性む刻々 と变化してきており, その要望に答えるため, 新規の粘着 剤開発を進めてきている。

本報告においては, 偏光板用粘着剤を中心に LCD 光学 フィルムに用いられる粘着剤の要求特性とその開発動向に ついて報告する。

\section{LCD 光学フィルム用粘着剤への要求特性}

LCD 光学フィルム用粘着剤には，まず，以下のような ディスプレイ用途として欠かすことのできない基本特性が 要求される11。

・透明性に優れ，ヘイズが低い

・光学的に等方性である

・経時や環境変化により着色, 変色しない

・表示に影響するような異物，欠点がない

偏光板の偏光特性や, 光学フィルムの光学補償特性に影 響を与えないために，透明性に優れ，へイズが低く，光学 的に等方性であることは必須の内容であると言える。また, 長期間の使用中に着色や変色しないことあ必要条件である。 これらの要求特性については, 粘着剤として使用される材 料自体に左右される場合が多く，使用する材料の純度や不 純物にも影響される。このため, 現在, 量産されている光 学用粘着剤のほとんどはアクリル系ポリマーを主体として 設計されている。また，異物や欠点については材料からの 混入ととあに, 粘着剤製造工程においてのコンタミも課題 となってくる。製造工程のクリーン化は必須であるが，特 に粘着剤を塗布するコーター周辺部ではクラス 100 程度の クリーン度が要求されてくる。

次に, 各 LCD の用途ごとに要求されている特性を図 2

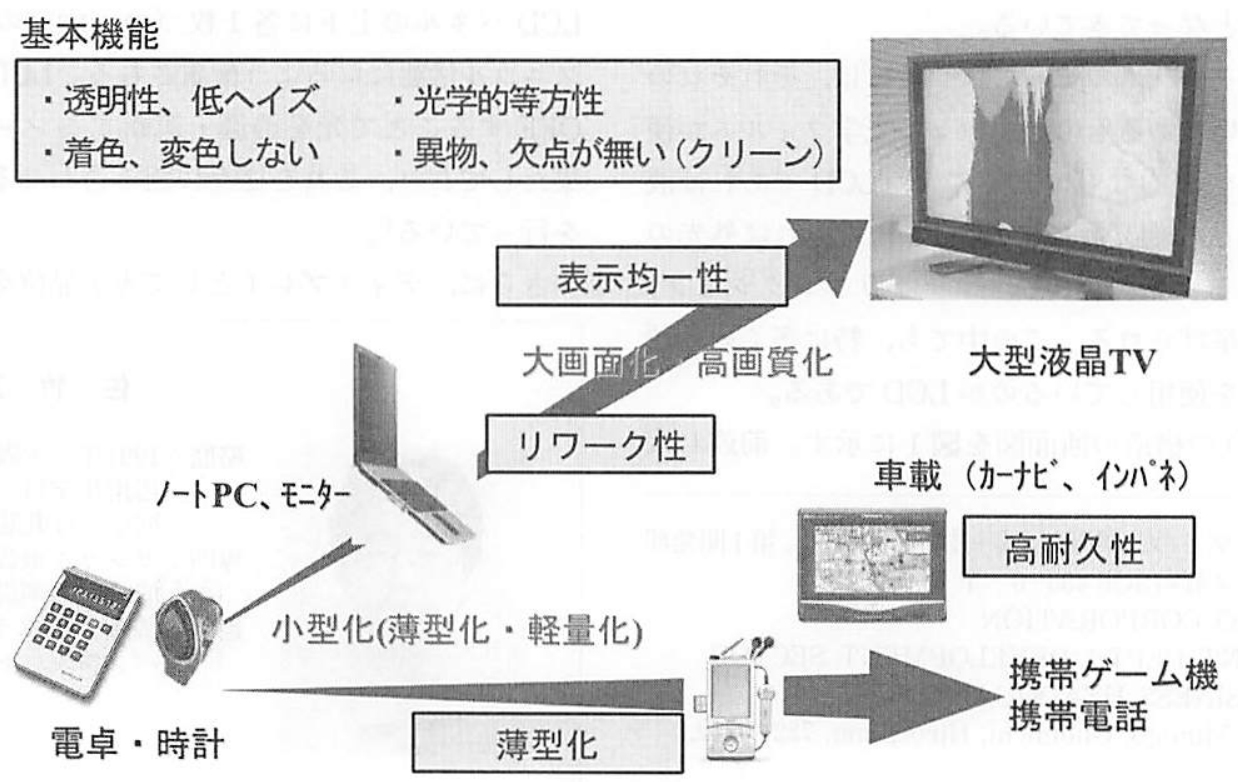

図 2 LCD の市場展開之粘着剤への要求特性 
にまとめた ${ }^{12)}$ 。前述のように，TV を中心として LCD の 用途が広がる中で梯々な特性が要求されてきている。従来 から要求されてきた特性であるがより高いレベルを要求さ れてきたものや, 新たな特性として要求され始めたものが あるが, 各用途によって要求特性が様々であることがわか る。各種要求特性に応じて様々な粘着剤設計が必要であり, また, 実際に開発を進めてきている。本報ではこれらの要 求特性の詳細ならびに要求特性満たす粘着剤設計に関して 報告する。

\section{3. 耐久性}

室内環境で使用されることを前提としたモニター・TV などの汎用用途に比べて, 屋外での使用を想定したカーナ ビゲーションや携帯電話などの高耐久用途ではより高い接 着信頼性が要求される ${ }^{13)}$ 。 LCD 光学フィルムに用いられ る粘着剤の接着不良の多くは, LCD パネルとの貼り合せ 界面で発生する。フィルム同士を貼り合せる粘着剤でも不 具合が発生することはあるが, LCD パネルと粘着剤界面 での不具合が大半を占める。 LCD パネルは一部のプラス チックセルを除き, ほとんど全てがガラスである。LCD に使用されるガラスは, 一般に無アルカリガラスと呼ばれ, 液晶の劣化を防ぐためにアルカリ分が除去されたものが用 いられる。この無アルカリガラスと粘着剤界面での接着信 頼性がポイントとなる。

接着不良としては, 大きく 2 つの不良モードが存在する。 一つは発泡と呼ばれるモードであり, もう一つは剥れと呼 ばれる現象である。

高温耐久性試験で発生する特徴的な不具合として, 発泡 と呼ばれるモードがある（写真 1)。発泡が発生すると, その部分は表示欠陷として認識され，ディスプレイとして は不良品となる。

発泡を観察すると, その形状は一律ではなく様々な形を していることがわかってきた。真円に近い球状のあのむあ れば, 細長い米粒状のものむ存在する。また, その形状は
一見ランダムに存在しているようであるが, 光学フィルム 面内のどの部分に発生しているかでおよそ分類できること がわかってきた。例えば，光学フィルムの面内中心付近で 発生した発泡は真円に近い形状をしている。一方で, 面内 端部付近では，米粒状の細長い形状になっている。さら に, 米粒状の気泡は, フィルムの中心方向に引っ張られた 形をとっていることが確認された。これら発泡の発生数や 大きさは，試験温度が高く，また長時間になることで拡大 する ${ }^{14}$ 。一方で, 同じ試験をオートクレーブなどの加圧条 件下で行うと著しく発泡が抑制できることも実験的に明ら かとなった ${ }^{15)}$ 。

これらの観察結果を基に発泡の発生メカニズムとしては, 大きく 2 つの段階があると推測した。

(1) 粘着剤中の水分, 残存溶剂, 残存モノマー等が加熱 により気化・膨張する段階

(2) 光学フィルムの収縮により拡大する段階 このメカニズムに基づいて発泡を抑制するための粘着剤設 計を進めてきた。特に (1) の気化・膨張を抑えることがポ イントとなる。即ち水分や残存溶剤, 残存モノマー等の気 化膨張する成分を低減し, 気化膨張を抑え込むだけの凝集 力を粘着剤に付与することが必要である。

粘着剂組成としては, 官能基モノマー成分を低減し吸水

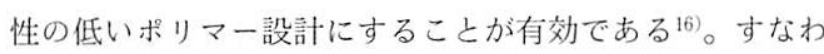
ち, カルボキシル基, 水酸基, アミノ基などの官能基成分 を低滅していくことが有効である。

また凝集力を付与するための手法としては，ポリマーの 高分子量化や粘着剂の高弾性率化, 架橋度アップなどが挙 げられる。

粘着剤ポリマーの分子量を制御することは有効な手法の ひとつであり，ポリマーをできるだけ高分子量化し，また， 低分子量分を低減して分子量分布を小さくすることで, 高 凝集力粘着剂を得ることができる ${ }^{17)}$ 。

以上の改善内容を粘着剂設計に盛り込むことで, 汎用用 途では 100 インチを超える超大型サイズに対応できる粘着

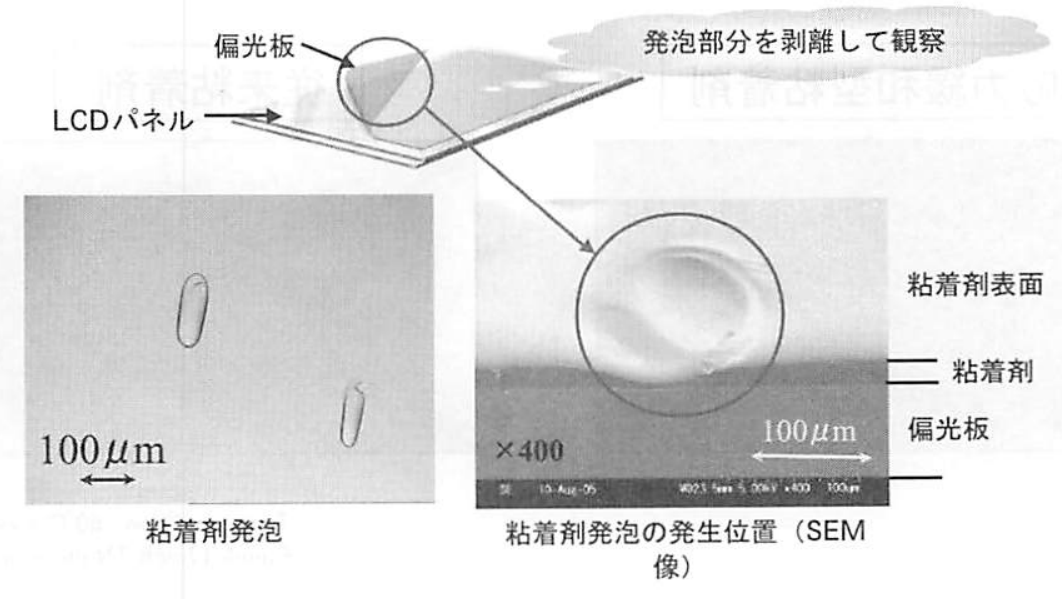

写真 1 発泡の形状 
剤を，また，高耐久用途では $105^{\circ} \mathrm{C} \times 1000 \mathrm{H}$ の試験にも耐 えうる粘着剤を開発するに至った。

次に, 剥れについて説明する。剥れは, 主に加湿試験時 に発生する不具合モードである。高温高湿雾囲気下では, ガラスと貼り合せた粘着剤界面に水が浸入し, 薄い水の膜 を形成する。このため，ガラスに対する粘着力は一時的に 低下する。同時に光学フィルムの变形が起きると粘着剤と ガラスの界面に応力が集中し，接着力が低下しているため に応力に耐えられなくなった粘着剤層が剥離することがあ る。これが，加湿䨌囲気下で発生する剥れ之呼ばれる不具 合である。

剥れを抑制するためには，水が浸入しても粘着力が低下 しないようにする必要がある。粘着剤中にシランカップリ ング剤を添加する手法むその一つである。アルコキシシリ ル基を有するシランカップリング剤は容易にガラス表面と 反応するため, 粘着剤とガラスとの接着性を高めることが でき，剥れを抑制できる18)。

\section{4. 表示均一性}

LCD の大型化に伴い重要視されてきた品質課題の一つ に, 表示均一性が挙げられる。面内のどの部分を見てむ均 一な表示品位が保たれることが, 重要な課題となっている。 代表的な不具合モードとして周辺ムラと呼ばれる現象があ る。LCD を黑表示にした際に画面周辺部で白く光が漏れ てくる現象（写真 $2:$ 従来粘着剂）であり, 高温・高湿度 下で一定時間経過した後に発生する。周辺ムラは試験温度 が高く, 試験サイズが大きいほど顕著に発生する傾向があ る。

周辺ムラの発生メカニズムを解明するために, 次のよう な実験が行われている。パターン 1 では，偏光板だけを一 定時間加熱した後に，ガラスに貼り合せてムラの発生状態 を確認した。一方，パターン 2 では，偏光板をガラスに貼 り合せた後に一定時間加熱し，その後周辺ムラを観察した。 パターン1ではムラは全く確認されないのに対して, パター

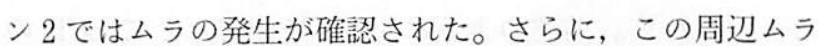
の発生したサンプルを室温で長時間放置しておくとムムラ は徐々に薄れていき最終的にはほぼ完全にもとの状態に戻 ることが確認された。これらの実験から, 周辺ムラは加熱 による偏光板の劣化で生じているのではなく，ガラスに貼 り合せた状態で加熱されることで生じる現象であり, また, 可逆的なむのであることが確認された ${ }^{199}$ 。

光学フィルムは偏光板に代表とされるように, 種々の高 分子フィルムを延伸して光学機能を発現させている。この ため, 熱や湿度雾囲気下では元の状態に戻ろうと収縮した り, 材料本来の線膨張によって膨張したり, 寸法变化を起 こす。特に偏光板はポリビニルアルコール（PVA）を 5 倍以上に延伸し偏光特性を発現させているため, 戻ろうと する力も大きくなる。実際には, 偏光板構成では PVA は 両側を保護フィルムで挟まれた構成をしており,さらに下 側の保護フィルムは粘着剤で液晶パネルに接着されて動き が拘束されている。このため, PVAの収縮応力が下側の 保護フィルムに集中し位相差が発生する。パネル上下の偏 光子により偏光状態か形成さ机黒表示となっている状態で, 偏光子の間に新たな位相差が発現することで偏光状態が解 消され, 光が漏れてくる。これが周辺ムラ発生のメカニズ ムと考えられる20)。

この時, 発生する位相差と応力に関しては次のような関 係が成り立つと考えられる211。

$$
\begin{aligned}
& \mathrm{R}=\mathrm{E} \times \mathrm{F} \times \mathrm{d} \\
& \mathrm{R}: \text { 発生する位相差 } \\
& \mathrm{E}: \text { 保護フィルム光弾性係数 } \\
& \mathrm{F}: \text { 保護フィルムにかかる仙力 } \\
& \mathrm{d}: \text { 保護フィルムの厚さ }
\end{aligned}
$$

式 (1) より, フィルムにかかる応力 $\mathrm{F}$ を低減することで, 発生する位相差を小さくすることができる。 応力 $\mathrm{F}$ は, さらに,

$$
\begin{gathered}
\mathrm{F}=\delta \times(\text { 偏光板の収縮量一粘着剤の伸び量 }) \\
\delta: \text { 保護フィルムの弾性率 }
\end{gathered}
$$

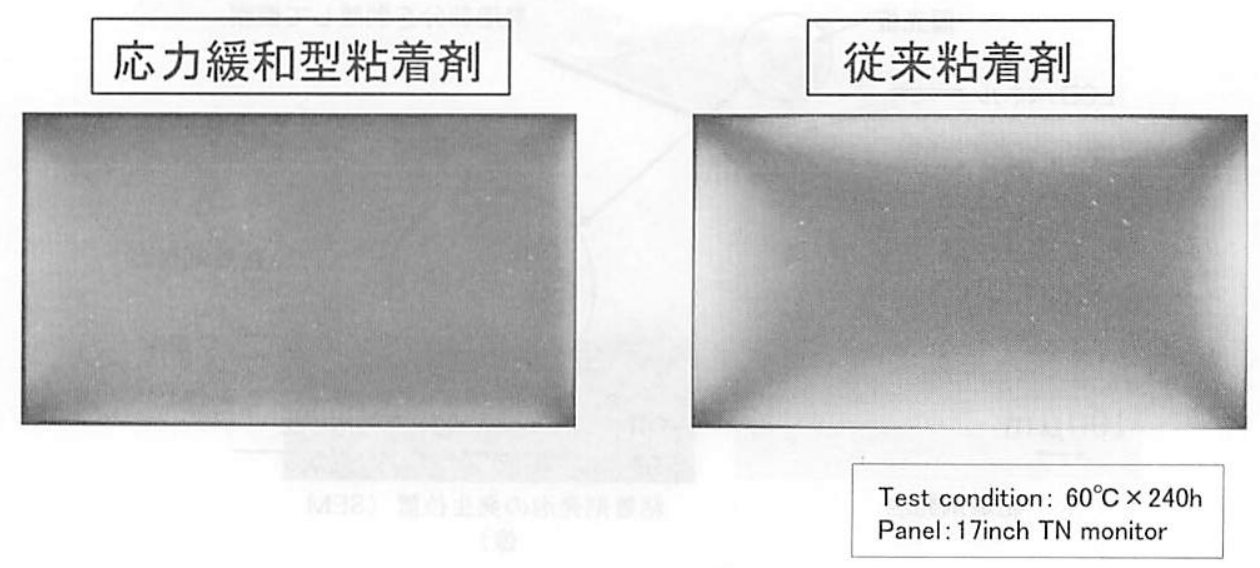

写真 2 周辺ムラの発生状況 


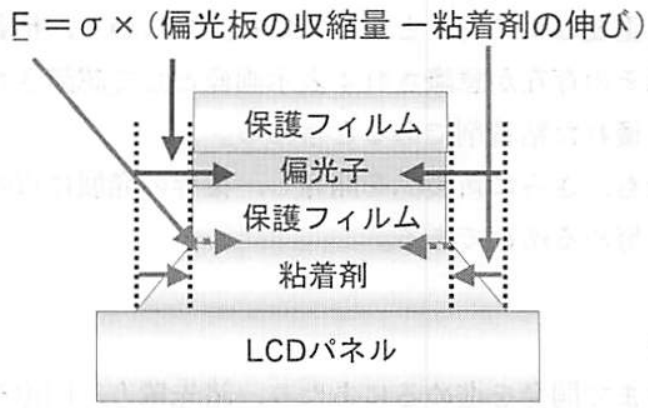

図 3 粘着剂の伸び

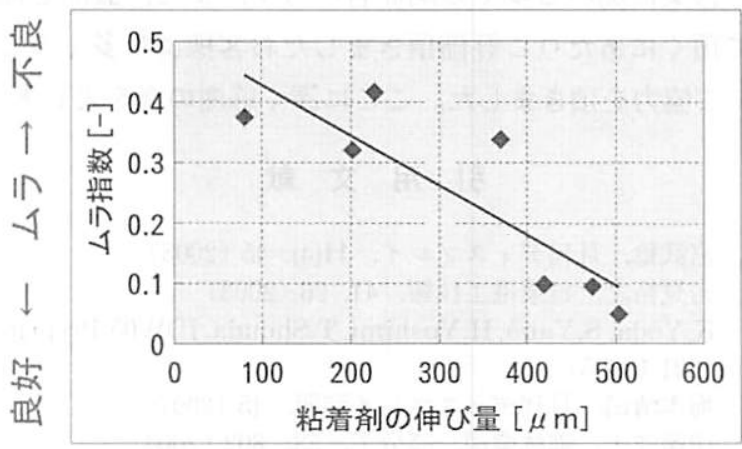

図 4 粘着剤の伸び量とムラの関係

と表される。偏光板の収縮量は, 所定温度条件下での偏光 板単体での収縮量を表す。粘着剤の伸びは，図 3 に示すよ うに，偏光板を粘着阂で液晶パネルに貼り合せた後，所定 温度条件下に放置した際の粘着剂の変形量を表す。

式 (2) から，偏光板の収縮に対して十分に追随するよう な伸びの大きな粘着剤を用い，偏光板をできるだけ拘束し なければ，応力Fの発生を抑えることができると考えられ る。実際に, 種々の粘着剂の伸び量と周辺ムラの関係を図 4 に示す。図 4 より, 粘着剤の伸び量の増加とともに, 周 辺么ラが低減されることが確認できた ${ }^{22)}$ 。また, TN モ一 ド液晶ディスプレイの表示ムラに対する粘着剤物性の関係 も明確になってきている23.24)。ここでは，粘着阂の物性に よってムラの形状や光が抜ける強さが変化する傾向が揌め てきている。

応力を低隇するために必要な粘着剤物性を FEM（有限 要素法）によってシミュレートする試みも行っている。計 算には, 種々の粘着剤物性, 偏光板物性, 偏光板の収縮挙 動を定量化しパラメーターとして用いた。また，計算によ り得られた結果と実際の周辺ムラの結果を付き合わせてい くことで, シミュレーションの精度を上げ, 応力緩和性を 付与した粘着剤設計に反映させていった ${ }^{19) 。 ~}$

これらの検討内容に基づき, 写真 2 に示すように周辺ム ラを抑え，表示均一性を改善した応力緩和型粘着阂を設計 することが可能となった ${ }^{25)}$ 。

\section{5. 再剥離性（リワーク性）}

携帯電話やノートパソコンなどでは, 薄型軽量化が重要
な要求特性となっており, 液晶セルのガラス厚みも $0.4 \mathrm{~mm}$ 以下になるなど薄型化が進んでいる。一方, TV 用途では 40 インチを超える大型化進んでおり，LCD パネルの薄型・ 大型化は必須の流れとなっている。

この動きの中で, 光学フィルム粘着剤にあ新たな特性が 要求されてきている。再剥離性（リワーク性）である。一 般にリワーク性という表現は剥がした粘着テープ・フィル ムを再利用する意図で使われることが多いが，光学フィル ム用途では, フィルムを再利用するケースは少ない。多く の場合, 被着体である LCD パネルを再利用するためにリ ワークという言葉を使用している。

光学フィルムが貼合された LCD パネルはその後の工程, 検査を経て出荷されるが, 検査の際に, フィルム自体に欠 陷があったりフィルムと液晶セルの間に異物を噛み込んだ 場合には，高価な液晶セルを再使用するために光学フィル ムを剥がす（リワークする）こととなる。リワークの際に 粘着凪の粘着力が高いと, 液晶部分のセルギャップが変っ たり，ガラスが破損して液晶セルが再使用できなくなると いった不具合が発生する。前述の様に， LCD パネルが薄 く大きくなるとこの不具合はますます顕著になる。

このため, 光学フィルム用粘着剤としては, 粘着力自体 は低く, 経時での上昇性が無く, 剥がす際に糊残りが発生 しないことが要求されてきている。

粘着剂の設計としては, 必要以上の接着要素を設計から 外し, 液晶セルへの接着力を低くしてリワーク性を向上さ せることが必要となる ${ }^{26)}$ 。アクリル系の粘着剤設計におい て, 接着性を付与したり, 架橋反応点として作用するため の共重合モノマーとしてアクリル酸や 2 ヒドロキシエチル アクリレートなどが一般的に用いられる。これらのモノマー に対して 5 ペンチルカルボキシアクリレートや 6 ヒドロキ シヘキシルアクリレートなどの比較的長いエステル鎖の先 端にカルボキシル基やヒドロキシル基などの極性基を持つ アクリレートモノマーを使用すると, 架橋効率が高くなる ことで架橋に寄与しない余分な極性官能基を低隇すること ができる27)。

リワーク性を向上するためのポイントとしては, やはり 而久性との両立をいかに実現するかが課題となる。単純に 接着性を低下させると, 先に挙げたような耐久性での不具 合 (発泡, 剥がれ) が発生することになる。このトレード オフの関係を解消するためには, 発泡, 剥がれのドライビ ングフォースとなる光学フィルムの変形による応力をガラ スとの接着界面に集中させないようにする必要がある。こ れを実現するためには，表示均一性を向上させるために粘 着剂に応力緩和性を付与したのと同様の設計が効果的であ り，ポリマーの低 $\mathrm{Tg}$ 化, 低分子量化, 低分子量成分の付 与や, 架橋阂の最適化による架橋密度の低下などが具体的 な設計手法として挙げられる。 
幣社では，これらの設計要素を盛り込み，従来の粘着剤 に比べて接着力を約 $1 / 2$ に低減した軽剥離粘着剤を開発 するに至っている28)。

LCD パネルに対する接着性を低減した粘着剤設計を行 うことは, 同時に光学フィルム自体への接着性（投錨性） む低下してしまうことが奬念される。投錨性の低下は, リ ワークの際にLCD パネル表面に粘着剤が残ってしまう， あるいは，工程でのハンドリングにおいて粘着剤の一部が 脱落するなどの不具合が生じる原因となる。さらに，光学 フィルムに使用される材料む，トリアセチルセルロースや ポリカーボネートからシクロオレフィン系のポリマーなど 多岐に渡ってきている。これらの素材の中には表面が非極 性のために著しく接着し難く，投錨性の確保が困難となる 場合がある。

この様な場合，粘着剤の設計だけで全ての要求を満たす ことは多くのトレードオフの課題を同時に解決する必要が あり，非常にハードルの高い設計となる。したがって，フィ ルムの表面状態を変性することで粘着剤との接着性を増し 投錨性を確保するなどの手法が取られることが多い。コロ ナ処理やプライマー処理はその一例と言える29.30)。

\section{6. 薄型化}

携帯電話・ノート PC 分野では光学フィルムの薄型化の 要求が強くなっている。特に携帯電話用途では, 光学特性 機能を高めるために, 種々の位相差板・補償板を積層する ことが通例であり, 薄型化を強く要望されている。フィル 么の積層枚数は, 多いものでは偏光板を含め 5 枚のフィル ムを積層した光学フィルムがある。薄型化の中で光学フィ ルム自体の薄型化も進んでいるが，粘着剤についても同様 に薄型化が要望されている。先の 5 枚のフィルムを使用し た光学フィルムの場合, 粘着剂層もフィルム層間用が 4 層, 液晶セルとの㙋り合せ用が 1 層, 合わせて 5 層が必要とな る。各粘着剤層の厚みは通常 $25 \mu \mathrm{m}$ であり, 5 層合わせ ると粘着剤部分だけで $125 \mu \mathrm{m}$ となる。

粘着剤層の厚みを低減する際に課題となってくるのは, 前述した耐久性とのトレードオフの関係である。やはり, 粘着剤厚みを低減するとそれだけ接着信頼性は低下するこ ととなる。粘着剤の接着信頼性を向上するためには，粘着 剂の組成を最適可することが最も有効である。粘着阂のフィ ルム層間の粘着剤に関しては現行の約半分の厚みである $12 \mu \mathrm{m}$ のものが実績化されている。また，最近ではさらな る薄型化として $5 \mu \mathrm{m}$ 厚の粘着剤も開発されてきている ${ }^{31}$ 。

\section{7. 結 言}

LCD 光学フィルム用粘着剂について様々な要求特性, 開発動向を述べてきた。光学フィルムの持っている機能を いかに維持し，LCD として優れた表示特性を発現するか
が最す重要なポイントとなっている。すなわち, 粘着剂と してはその存在が意識されず表示画像として認識されない ほど，優れた粘着剤であると言える。

今後も, さらに新製品を開発し, 業界の発展に貢献でき るよう努める所存である。

\section{謝辞}

これまで開発を進めるにあたり, 諸先輩方, 同僚を始め として, 開発, 資材, 製造, 生産技術, 品質保証, 物流, 知 財, 営業に関わる多くの関係者の方々, また, 製品を採用 して頂くにあたりご評価頂きましたお客様より多くのご助 言，ご協力を頂きました。ここに深く感謝の意を表します。

\section{引用 文 献}

1）宮武稳, 月刊ディスプレイ，11(4)，45 (2005)

2）吉見裕之，日東電工技報，41，26（2003）

3) K.Yoda, S.Yano, H.Yoshimi, T.Shouda, IDW05 Preprints, 1321 (2005)

4）梅本清司，月刊ディスプレイ別冊， 45 (2007)

5）伊藤洋士，御林慶司，高分子， 53, 802 (2004)

6）中荀登志雄，機能材料， 19(12), 47 (1999)

7) S.Kobayashi, H.Shibata, Y.Takahashi, T.Shouda: IDW99 Preprints, 391 (1999)

8）濱本大介, 楠本誠一, 正田位守, 第 13 回ポリマー材料フォー ラム予稿集，40 (2004)

9）“粘着テープ物語 (現代編)”, 日東電工株式会社, 83 (2001)

10）佐竹正之, 第 16 回ファインテックジャパン講演要旨集（2006）

11）佐竹正之, 小笠原晶子, 外山雄祐, 第 46 回日本接着学会年 次大会予稿集，183 (2008)

12）佐竹正之, 日本接着学会粘着研究会 25 周年記念セミナー講 演要旨集, 77 (2006)

13）佐竹正之, “粘着技術の $3 \mathrm{~A} ”$, リアライズ理工センター, 324 (2006)

14）外山雄祐, 佐竹正之, 日本接盖学会第 44 回年次大会講演要 旨集, 63 (2006)

15）山岡尚志, 大泉新一, 佐竹正之, 藤村保夫, 日東技法, 33 , 41 (1995)

16) 特許 3783971 号

17）佐竹正之, “接着之はく離のための高分子”, シーエムシー出 版, 255 (2006)

18）特許 2549388 号

19) M.Satake, T.Shouda, S.Ooizumi, K.Miyauchi, K.Kojima, IDW98 Preprints, 251 (1998)

20）佐竹正之，接着の技術，25(1)，25（2006）

21）小笠原晶子, 佐竹正之, 外山雄祐, 高分子討論会予稿集, 54, 5440 (2005)

22）佐竹正之，接着， 50, 58 (2006)

23) K. Yano, A. Ogasawara, T. Chiba, N. Nitta, T. Shouda, IDW07 Preprints, 2061 (2007)

24）矢野浩平，千葉剛，小笠原晶子，佐竹正之，映像情報メディ 了学会誌, 82, 1576 (2008)

25）佐竹正之，第 70 回ニューフロンティア材料部会講演資料, (2006)

26）佐竹正之, 第 27 回粘着技術研究会講演要旨集，35（2006）

27) 特許 3281490 号

28）佐竹正之，高橋寧，日東技報，38，52（2000）

29) 特竍 4007920 号

30) 特許 4020617 号

31) 特許 4140736 号 